\title{
Potential Treatment of Fatty Liver with 14-Day Subcutaneous Injections of Glucagon ${ }^{1}$
}

\author{
G. Bobe, B. N. Ametaj, J. W. Young, and D. C. Beitz \\ Nutritional Physiology Group, \\ Department of Animal Science, \\ lowa State University, Ames 50011-3150
}

\section{ABSTRACT}

Fatty liver is a major metabolic disease of dairy cows in early lactation that can be treated with 14 -d continuous, intravenous infusions of $10 \mathrm{mg} / \mathrm{d}$ of glucagon. The objective was to test whether similar effects can be obtained with 14-d subcutaneous 7.5- or 15 -mg daily dosages of glucagon beginning at $d 8$ postpartum. Multiparous Holstein cows $(n=32)$ were grouped on the basis of their liver triacylglycerol concentration at $d 8$ postpartum into "normal" $(\mathrm{n}=8$; triacylglycerol $<1 \%$ liver wet wt) and "susceptible" ( $\mathrm{n}=24$; triacylglycerol $>1 \%$ liver wet wt) cows. Susceptible cows were assigned randomly to three groups and beginning at $\mathrm{d} 8$ postpartum received $0,2.5$, or $5 \mathrm{mg}$ of glucagon in $60 \mathrm{ml}$ of saline by subcutaneous injections every $8 \mathrm{~h}$ for $14 \mathrm{~d}$. Beginning at $\mathrm{d} 8$ postpartum, normal cows received 60 $\mathrm{ml}$ of saline by subcutaneous injections every $8 \mathrm{~h}$ for $14 \mathrm{~d}$. Both dosages of glucagon increased concentrations of plasma glucose and insulin and decreased concentrations of plasma nonesterfied fatty acids. Glucagon injections of $15 \mathrm{mg} / \mathrm{d}$ decreased concentrations of liver triacylglycerol in cows older than $3.5 \mathrm{yr}$, but not in younger multiparous cows. Our results document that subcutaneous injections of glucagon have the potential to decrease the degree of fatty liver in older dairy cows in early lactation.

(Key words: dairy cow, early lactation, fatty liver, glucagon)

Abbreviation key: AMN $=\alpha$-amino nitrogen, TAG $=$ triacylglycerol.

\section{INTRODUCTION}

Fatty liver (i.e., hepatic lipidosis) is recognized as a major metabolic disease that affects up to $50 \%$ of dairy

\footnotetext{
Received September 4, 2002.

Accepted February 18, 2003.

Corresponding author: D. C. Beitz; e-mail: dcbeitz@iastate.edu.

${ }^{1}$ Publication of the Iowa Agriculture and Home Economics Experiment Station, Ames; Project Number 3801. Preliminary reports have been presented [FASEB J. 16: A618 and A635, 2002; J. Dairy Sci. 85(Suppl. 1): 64-65, 2002].

${ }^{2}$ Corresponding author: D. C. Beitz; e-mail: dcbeitz@iastate.edu
}

cows in early lactation (Jorritsma et al., 2001). Fatty liver also increases the incidence and severity of other diseases (Veenhuizen et al., 1991; Rehage et al., 1996; Zerbe et al., 2000) and decreases milk production and reproductive performance (Veenhuizen et al., 1991; Wensing et al., 1997), thereby costing millions of dollars yearly in treatment, replacement, and production losses (Littledike et al., 1981). Cows with fatty liver are treated, similar to clinically ketotic cows, with an oral glucose precursor in mild cases (Studer et al., 1993) and with intravenous infusions of dextrose combined with glucocorticoids (Shpigel et al., 1996) or insulin (Sakai et al., 1993) in severe cases to improve the carbohydrate status of the cow. These compounds are effective in treating ketosis but have not been tested for efficacy in treating fatty liver. In a previous study in our group (Hippen et al., 1999), we demonstrated that continuous, intravenous glucagon infusions for $14 \mathrm{~d}$ beginning at $d 21$ postpartum decreased liver triacylglycerol (TAG) concentrations and the incidence of ketosis in dairy cows that were subjected to a protocol to induce fatty liver and ketosis.

Glucagon, containing 29 amino acids, is a pancreatic hormone that improves carbohydrate status of cows by stimulating hepatic gluconeogenesis, glycogenolysis, amino acid uptake, and ureagenesis (Flakoll et al., 1994; Donkin and Armentano, 1995). The effect of glucagon on lipid metabolism is both direct and indirect because glucagon directly increases lipolysis in adipose tissue but indirectly decreases lipolysis by increasing concentrations of plasma glucose and insulin (Brockman et al., 1975). Intravenous infusions of glucagon, however, are not practical for on-farm use, and fatty liver is not induced artificially on farms by feed restriction and 1,3-butanediol administration as done by Hippen et al. (1999). We showed in preliminary experiments that single subcutaneous injections of 2.5 and $5 \mathrm{mg}$ of glucagon, a more practical form of glucagon administration, increases concentrations of plasma glucagon, glucose, and insulin for 4,5 , and $2 \mathrm{~h}$, respectively (Bobe et al, 2003).

Therefore, the objective of the current study was to determine whether subcutaneous injections of 7.5 and 
$15 \mathrm{mg} / \mathrm{d}$ of glucagon for $14 \mathrm{~d}$ starting at d 8 postpartum could be used to treat fatty liver. More specifically, the objective was to determine the effects of those daily dosages of glucagon on the composition of liver, the concentrations of key constituents in plasma, and the production and composition of milk.

\section{MATERIALS AND METHODS}

\section{Experimental Design}

During their final 4 wk prepartum, 32 multiparous Holstein cows were housed in a straw-bedded free-stall barn; however, the number at any given time varied depending on the number of cows at that stage of gestation. The available group was offered a typical NRC recommended (2001) transition dry-cow TMR (Table 1) at $12.8 \mathrm{~kg}$ (9.6 kg DM) per cow daily, which was consumed within $6 \mathrm{~h}$. Additional grass hay was available ad libitum. To increase the probability for postpartal fatty liver and susceptibility to ketosis, cows were haltered in a tie-stall barn daily for $2 \mathrm{~h}$, and each cow was offered, in addition to the TMR and hay, $6 \mathrm{~kg}$ of cracked corn. Most cows consumed the corn within the $2 \mathrm{~h}$; however, we did not measure the amount of corn refused. Therefore, prepartal DMI for individual cows was not controlled completely. We assume that prepartal DMI was not different between treatments and between age of cow-groups within treatment because BCS between treatments and between age of cow-groups within treatment during the last month before parturition were not significantly different (Table 2). All cows were visually healthy before parturition.

Feeding additional corn for 4 wk was not as effective in inducing clinical fatty liver (liver TAG > 8\% liver wet wt) as it was previously (Hippen et al., 1999). There are several possible explanations. In comparison to the previous study (Hippen et al., 1999), these cows had no previous history of ketosis. Cows in the current study had lower BCS before calving, with no cow having a BCS greater than 4.25 prepartum (Table 2). Cows in the current study lost less than one third of the BCS (Table 2) that cows lost in the previous study (Hippen et al., 1999). Both factors are associated with increased risk for fatty liver (Wensing et al., 1997; Jorritsma et al., 2001). Additionally, the concentration of CP in the postpartal diet was lower than in the previous study (Hippen et al., 1999), which is associated with increased risk for fatty liver (Murondoti et al., 2002). Feeding additional corn did not increase BCS more than 0.25 on the average (Table 2), which is similar to the increase in the previous study (Hippen et al., 1999).

During the postpartal period, all cows were housed in a tie-stall barn and had free access to a typical NRCrecommended TMR for high-producing multiparous
Table 1. Ingredient composition of diets fed to cows during the 28d prepartal and 43-d postpartal periods.

\begin{tabular}{|c|c|c|}
\hline Item & Prepartum $^{1}$ & Postpartum \\
\hline \multirow{2}{*}{\multicolumn{3}{|c|}{ Ingredient }} \\
\hline & & \\
\hline Alfalfa haylage & 11.8 & 22.6 \\
\hline Corn, cracked & 25.2 & - \\
\hline Corn grain, ground & - & 30.5 \\
\hline Corn gluten feed & - & 9.8 \\
\hline Corn silage & - & 20.9 \\
\hline Cotton seed & 6.5 & 7.4 \\
\hline Grass hay & ad libitum & - \\
\hline Soybean meal & - & 5.7 \\
\hline Dry cow mineral $^{2}$ & 1.4 & - \\
\hline Lactating mineral $^{3}$ & - & 3.1 \\
\hline Limestone & & - \\
\hline SoyChlor6 ${ }^{4}$ & 1.8 & - \\
\hline Transition premix ${ }^{5}$ & 2.3 & - \\
\hline \multicolumn{3}{|l|}{ Nutrient } \\
\hline $\mathrm{CP}$ & 15.1 & 16.8 \\
\hline RUP & 5.58 & 5.99 \\
\hline $\mathrm{NE}_{\mathrm{L}}(\mathrm{Mcal} / \mathrm{kg})$ & 1.50 & 1.72 \\
\hline Ether extract & 2.68 & 4.44 \\
\hline NDF & 40.3 & 29.1 \\
\hline $\mathrm{ADF}$ & 23.8 & 16.5 \\
\hline $\mathrm{NFC}^{6}$ & 32.0 & 43.0 \\
\hline Ash & 10.0 & 6.64 \\
\hline $\mathrm{Ca}$ & 1.11 & 1.15 \\
\hline $\mathrm{P}$ & 0.35 & 0.49 \\
\hline $\mathrm{Na}$ & 0.10 & 0.21 \\
\hline $\mathrm{K}$ & 1.03 & 1.14 \\
\hline $\mathrm{Cl}$ & 0.81 & 0.24 \\
\hline $\mathrm{S}$ & 0.32 & 0.21 \\
\hline
\end{tabular}

${ }^{1}$ The TMR was offered to cows as a group at $12.8 \mathrm{~kg}(9.6 \mathrm{~kg} \mathrm{DM})$ per cow daily, which was consumed within $6 \mathrm{~h}$. Grass hay included in the TMR was $37.9 \%$ of the TMR DM. Additional grass hay was available ad libitum. Cows were haltered in a tie-stall barn daily for $2 \mathrm{~h}$, and each cow was offered $6 \mathrm{~kg}$ of cracked corn in addition to the TMR and hay. Most cows consumed the corn within the $2 \mathrm{~h}$; however, we did not measure the amount of corn refused.

${ }^{2}$ Dry cow mineral obtained from Heart of Iowa (Gilbert, IA). Dry cow mineral contained on a DM basis $21.48 \% \mathrm{CP}, 6.44 \%$ RUP, 0.79 $\mathrm{Mcal} / \mathrm{kg} \mathrm{NE}, 2.34 \% \mathrm{ADF}, 3.90 \% \mathrm{NDF}, 10.74 \%$ nonfiber carbohydrate, $7.81 \%$ starch, $0.39 \%$ lipid, $50.63 \%$ ash, $7.42 \% \mathrm{Ca}, 0.27 \% \mathrm{P}, 2.24 \%$ $\mathrm{Mg}, 0.91 \% \mathrm{~K}, 2.49 \% \mathrm{Na}, 3.90 \% \mathrm{Cl}, 7.37 \% \mathrm{~S}, 3.56 \mathrm{mg} / \mathrm{kg}$ of Co, 254.14 $\mathrm{mg} / \mathrm{kg}$ of Cu, $1524.81 \mathrm{mg} / \mathrm{kg}$ of Fe, $12.20 \mathrm{mg} / \mathrm{kg}$ of I, $1.016 .54 \mathrm{mg} / \mathrm{kg}$ of Mn, $9.77 \mathrm{mg} / \mathrm{kg}$ of Se, $2236.39 \mathrm{mg} / \mathrm{kg}$ of Zn, $136.73 \mathrm{kIU} / \mathrm{kg}$ of vitamin A, $39.23 \mathrm{kIU} / \mathrm{kg}$ of vitamin D, and $750.09 \mathrm{kIU} / \mathrm{kg}$ of vitamin E.

${ }^{3}$ Lactating mineral obtained from Heart of Iowa. Lactating mineral contained on a DM basis $24.91 \%$ CP, 0\% RUP; $75.73 \%$ ash, $13.83 \%$ $\mathrm{Ca}, 3.66 \% \mathrm{P}, 3.14 \% \mathrm{Mg}, 0.07 \% \mathrm{~K}, 7.70 \% \mathrm{Na}, 5.42 \% \mathrm{Cl}, 0.22 \% \mathrm{~S}, 8.03$ $\mathrm{mg} / \mathrm{kg}$ of Co, $451.41 \mathrm{mg} / \mathrm{kg}$ of Cu, $6327.41 \mathrm{mg} / \mathrm{kg}$ of Fe, $21.58 \mathrm{mg} / \mathrm{kg}$ of I, $1855.15 \mathrm{mg} / \mathrm{kg}$ of Mn, $16.20 \mathrm{mg} / \mathrm{kg}$ of Se, $2535.57 \mathrm{mg} / \mathrm{kg}$ of Zn, $152.03 \mathrm{kIU} / \mathrm{kg}$ of vitamin A, $33.05 \mathrm{kIU} / \mathrm{kg}$ of vitamin D, and 1316.54 $\mathrm{kIU} / \mathrm{kg}$ of vitamin $\mathrm{E}$.

${ }^{4}$ SoyChlor6 obtained from West Central Soy (Ralston, IA). SoyChlor6 contained on a DM basis $16 \%$ CP, $3.1 \%$ crude fat, $13.0 \%$ crude fiber, $26.5 \% \mathrm{ADF}, 2.0 \% \mathrm{Ca}, 0.25 \% \mathrm{P}, 1.0 \% \mathrm{Mg}, 0.4 \% \mathrm{~K}, 0.2 \%$ $\mathrm{S}$, and $4.1 \% \mathrm{NaCl}$.

${ }^{5}$ Transition premix obtained from Heart of Iowa. Transition premix contained on a DM basis $44.10 \% \mathrm{CP}, 14.63 \%$ RUP, $1.59 \mathrm{Mcal} / \mathrm{kg} \mathrm{NE}$, $10.56 \% \mathrm{ADF}, 14.63 \% \mathrm{NDF}, 10.24 \%$ nonfiber carbohydrate, $5.60 \%$ starch, $10.68 \%$ lipid, $23.84 \%$ ash, $3.26 \% \mathrm{Ca}, 0.71 \% \mathrm{P}, 2.00 \% \mathrm{Mg}$, $0.92 \% \mathrm{~K}, 0.22 \% \mathrm{Na}, 0.30 \% \mathrm{Cl}, 2.73 \% \mathrm{~S}, 1.51 \mathrm{mg} / \mathrm{kg}$ of Co, $108.02 \mathrm{mg} /$ $\mathrm{kg}$ of $\mathrm{Cu}, 648.13 \mathrm{mg} / \mathrm{kg}$ of Fe, $5.19 \mathrm{mg} / \mathrm{kg}$ of I, $432.09 \mathrm{mg} / \mathrm{kg} \mathrm{Mn}, 3.87$ $\mathrm{mg} / \mathrm{kg}$ of Se, $1123.43 \mathrm{mg} / \mathrm{kg}$ of $\mathrm{Zn}, 71.13 \mathrm{kIU} / \mathrm{kg}$ of vitamin A, and $19.05 \mathrm{kIU} / \mathrm{kg}$ of vitamin D, $355.69 \mathrm{kIU} / \mathrm{kg}$ of vitamin $\mathrm{E}$.

${ }^{6}$ Nonfiber carbohydrate $=100-(\% \mathrm{NDF}+\% \mathrm{CP}+\%$ ether extract $+\%$ ash). 
Table 2. Body condition scores and incidence of metabolic and physiological disorders in each treatment group prior to the injection period. ${ }^{1}$

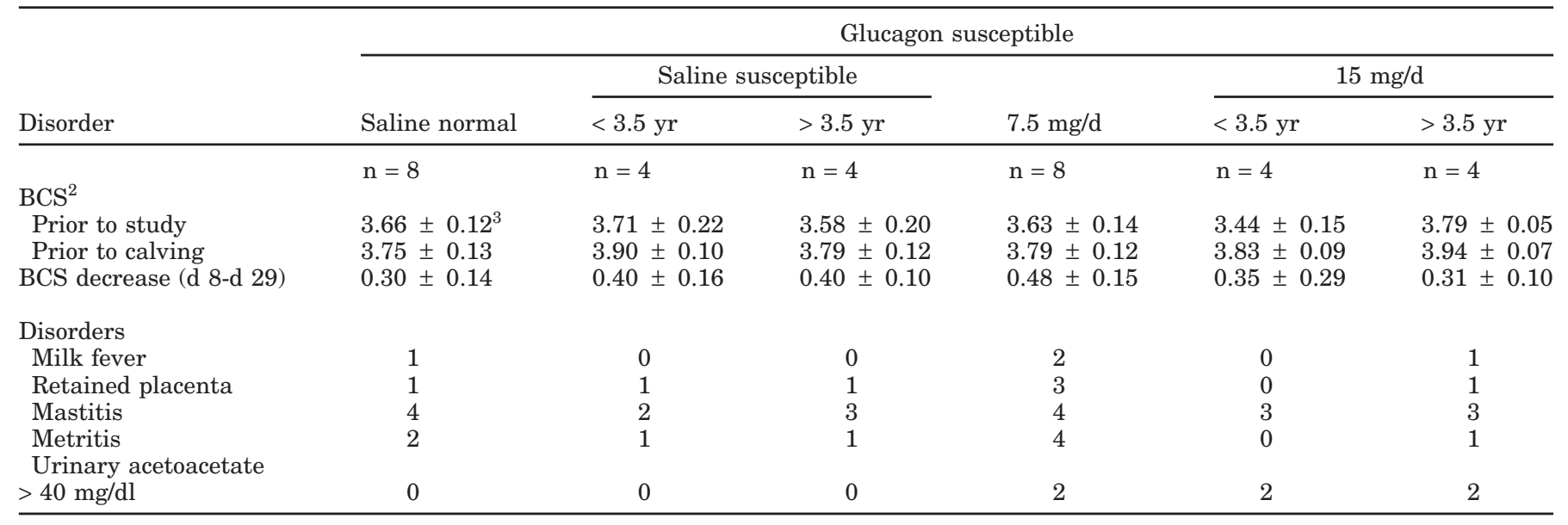

${ }^{1}$ Cows $(\mathrm{n}=8)$ with a liver triacylglycerol (TAG) concentration of $<1 \%$ of liver wet wt (saline normal) were injected subcutaneously with $60 \mathrm{ml}$ of $0.15 \mathrm{M} \mathrm{NaCl}(\mathrm{pH} 10.25)$ every $8 \mathrm{~h}$ for $14 \mathrm{~d}$ starting at d 8 postpartum. Cows $(\mathrm{n}=24 ; 8$ cows randomly assigned to each treatment group) with a liver TAG concentration of $>1 \%$ of liver wet wt were injected subcutaneously every $8 \mathrm{~h}$ with 0 (saline susceptible), 2.5 (7.5 $\mathrm{mg} / \mathrm{d}$ ), or $5(15 \mathrm{mg} / \mathrm{d}) \mathrm{mg}$ of glucagon dissolved in $60 \mathrm{ml}$ of $0.15 \mathrm{M} \mathrm{NaCl}$ (final $\mathrm{pH} 10.25$ ) for $14 \mathrm{~d}$ starting at d 8 postpartum.

${ }^{2}$ Body condition score: 1 = extremely thin to 5 = extremely obese (Edmonson et al., 1989). Body condition scores were determined by three trained independent evaluators before the study, which is $28 \mathrm{~d}$ before projected calving date and before feeding extra corn, before calving, which is on the average $4 \mathrm{~d}$ before calving, before the injection period at $\mathrm{d} 8$ postpartum, and one week after the injection period at $\mathrm{d} 29$ postpartum.

${ }^{3}$ Mean \pm SEM.

cows (Table 1). Fresh feed was offered daily at 0800 and $1800 \mathrm{~h}$. All cows were managed and treated in accordance with guidelines established by the Iowa State University Committee on Animal Care. From calving to d 8 postpartum, the incidence of metabolic and physiological disorders was not different between treatment groups as well as between age of cow-groups within treatment (Table 2).

At $d 8$ postpartum, cows were divided into two groups. Cows $(\mathrm{n}=8)$ with liver TAG concentrations of $<1 \%$ of liver wet wt (saline normal) were injected subcutaneously with $60 \mathrm{ml}$ of $0.15 \mathrm{M} \mathrm{NaCl}(\mathrm{pH} \mathrm{10.25)}$ every $8 \mathrm{~h}$ for $14 \mathrm{~d}$ starting at $\mathrm{d} 8$ postpartum. Cows $(\mathrm{n}=24$; eight cows randomly assigned to each treatment) with liver TAG concentrations of $>1 \%$ of liver wet wt were injected subcutaneously every $8 \mathrm{~h}(0600,1400$, and $2200 \mathrm{~h})$ with 0 (saline susceptible), $2.5(7.5 \mathrm{mg} / \mathrm{d})$, or $5(15 \mathrm{mg} / \mathrm{d}) \mathrm{mg}$ of lyophilized bovine glucagon (donated by Eli Lilly \& Co., Indianapolis, IN) dissolved in $60 \mathrm{ml}$ of $0.15 \mathrm{M} \mathrm{NaCl}$ (final $\mathrm{pH} 10.25$ ) for $14 \mathrm{~d}$ starting at $1400 \mathrm{~h}$ of $\mathrm{d} 8$ postpartum. Day 8 postpartum was chosen as the starting day of the injection period because preliminary studies showed that concentrations of liver TAG were highest at d 8 postpartum (Bobe, 2002; unpublished results). The effectiveness of subcutaneous injections of glucagon for prevention of fatty liver starting at d 2 postpartum was tested in a companion study (Nafikov et al., 2002).

To prevent adherence of glucagon, all glassware and utensils were rinsed with $1 \% \mathrm{BSA}$ in $0.15 \mathrm{M} \mathrm{NaCl}$ (wt/ vol) before use. Fresh glucagon was prepared every other day and stored at $4^{\circ} \mathrm{C}$ until injection. For subcutaneous glucagon injections, the area between the fifth to seventh intercostal space, 30 to $60 \mathrm{~cm}$ to the right and left of the dorsal midline, was clipped at $\mathrm{d} 8$ postpartum. Before and after injection, the injection site was cleaned and disinfected with $70 \%$ ethanol. The injection site was changed every day to avoid inflammation. We did not observe any irritation or inflammation of injection sites.

\section{Sampling and Analyses}

Liver. Liver samples were obtained by puncture biopsies at d $-4,3,8,11,15,22,28,36$, and 43 postpartum. After securing the cow in a livestock handling chute, $10 \mathrm{ml}$ of Xylocaine (lidocaine hydochloride, 2\%; Med. Tech. Inc., Elkwood, KS) was injected into the 10th or 11th intercostal space 30 to $40 \mathrm{~cm}$ to the right of the dorsal midline with a 20 -gauge needle. The injection was placed both superficially and deep into the muscle layer to anesthetize the incision area completely. Hair surrounding the anesthetized area was clipped, scrubbed with Betadine (povidone-iodine, 7.5\%; Purdue Frederick Co., Norwalk, CT), shaved, scrubbed again, rinsed, swabbed three times with $70 \%$ ethanol, and then sterilized with a tincture of iodine. The location of the liver was determined using a commercially available real-time ultrasound system (Aloka Micrus 500; distributed by Corometrics Inc., Wallingford, CT) with a 3.5 
Mhz linear transducer (Aloka model UST-5011U-3.5). A vertical incision about $2 \mathrm{~cm}$ in length was made through the skin and fascia in the anesthetized area. A medium-sized cannula ( $\sim 6 \mathrm{~mm}$ o.d. and $\sim 4 \mathrm{~mm}$ i.d.) surrounding a solid, retractable needle-pointed trocar was inserted through the muscle and peritoneum into the liver in a direction toward the left shoulder. After boring the cannula into the liver, a sample ( 1 to $3 \mathrm{~g}$ ) was obtained through creating a vacuum by drawing back the trocar and then flexing the tip of the cannula upward and gently pushing forward. The liver sample was expelled onto a clean Teri Wipe, blotted free of blood, cut into $2-\mathrm{cm}$ sections, and placed into storage vials (catalog number 5012-0020; Nalgene Co., Rochester, NY) that were placed immediately in liquid nitrogen and then later stored at $-80^{\circ} \mathrm{C}$ until chemical analysis. After the biopsy, the incision was closed with two surgical staples, wiped clean, and treated with Nitrofurazone Dressing (Durvet Inc., Blue Springs, MO). The cow then was returned to her stall and monitored for labored breathing, signs of discomfort, elevated body temperature, and swelling at the biopsy site. One or more of those side effects occurred after less than $5 \%$ of all biopsies. The surgical staples were removed 7 to $10 \mathrm{~d}$ after biopsy.

For liver lipid analysis, $250 \mathrm{mg}$ of tissue was sonicated for $30 \mathrm{~s}$ in $10 \mathrm{ml}$ of chloroform-methanol (2:1, vol/ vol) in a screw-top $25 \times 150 \mathrm{~mm}$ extraction tube (model 350 sonifier; Branson Sonic Power Corp., Danbury, CT). After samples were shaken for $12 \mathrm{~h}$ (model 75 wristaction shaker; Burrel Scientific, Pittsburgh, PA), $4 \mathrm{ml}$ of Millipore water was added, and then samples were centrifuged for $20 \mathrm{~min}$ at $500 \times \mathrm{g}$ (model $\mathrm{K}$ centrifuge; International Equipment Co., Needham Heights, MA). After centrifugation, the methanol-water layer was aspirated and discarded. The remaining sample and chloroform were stored overnight at $4^{\circ} \mathrm{C}$. The next day, the sample and chloroform were filtered with slight suction through a Buchner funnel and a 42.5-mm glass microfiber filter (Whatman International Ltd., Maidstone, England) into a preweighed scintillation vial, which was followed by three washes with 2,2 , and $4 \mathrm{ml}$ of chloroform, respectively. Extracted liver lipid samples were dried in the vials under forced air for $6 \mathrm{~h}$ at $50^{\circ} \mathrm{C}$ (SC/48R sample concentrator; Brinkmann Instruments, Inc., Westbury, NY), and the vials then were filled with nitrogen. Samples were stored for $12 \mathrm{~h}$ at room temperature and then weighed to determine total lipids. Total lipid analysis was done in triplicates. For liver TAG determination, dried lipids were dissolved in $5 \mathrm{ml}$ of $1 \%$ Triton X-100 (Fisher Scientific, Fair Lawn, $\mathrm{NJ}$ ) in $0.15 \mathrm{M} \mathrm{NaCl}$ at $37^{\circ} \mathrm{C}$, and liver TAG concentrations were determined for each total lipid sample in triplicate (TAG kit number T7532; Pointe Scientific,
Lincoln Park, MI) on a microplate spectrophotometer (SPECTRAmax PLUS, Sunnyvale, CA). In comparison to base hydrolysis (Hippen et al., 1999), enzymatic determination gave lower estimates $(<1 \%$ of liver wet wt) of liver TAG (data not shown). The difference in estimates, however, is far too small to explain the much higher concentrations of liver TAG in the previous study (Hippen et al., 1999).

For liver glycogen determination, $400 \mathrm{mg}$ of tissue and $5 \mathrm{ml}$ of $0.15 \mathrm{M} \mathrm{NaCl}$ were homogenized (model 106 homogenizer; Talboys Instrument Corp., Emerson, NJ), and the sample then was centrifuged at $4^{\circ} \mathrm{C}$ for $20 \mathrm{~min}$ at $2000 \times g$. The supernatant was transferred to a sterile polypropylene centrifuge tube. Four samples $(300 \mu \mathrm{l})$ of supernatant were transferred into microcentrifuge tubes $(1.5 \mathrm{ml})$. One sample was stored at $4^{\circ} \mathrm{C}$ for determination of free glucose. To each of the other three samples, $300 \mu \mathrm{l}$ of amyloglucosidase $(15 \mathrm{~g} / \mathrm{L}$, catalog number A 7255; Sigma, St. Louis, MO) and $300 \mu \mathrm{l}$ of a solution, containing $50 \mathrm{mM}$ pyridine acetate (catalog number P 4036; Sigma) and 0.2\% sodium azide (catalog number S 8032; Sigma) was added for determination of total glucose. The mixture then was stored at $37^{\circ} \mathrm{C}$ for $4 \mathrm{~h}$. Glucose concentrations (glucose kit number 315; Sigma) were determined in triplicate for each of the four samples on a microplate spectrophotometer (SPECTRAmax PLUS). Glycogen concentrations in liver were calculated as the difference between total and free glucose.

Plasma. Blood samples were collected at $0700 \mathrm{~h}$ from the coccygeal vein at $d-4,3,8$ (before first injection), 9, 11, 15, 22 (after last injection), 23, 28, 36, and 43 postpartum. During the 14-d treatment with glucagon, we sampled $1 \mathrm{~h}$ after the morning injection, because this was when responses of plasma glucose, glucagon, and insulin to glucagon injections were highest. Blood was collected into 10-ml Vacutainer tubes (Beckton Dickinson and Co., Rutherford, NJ) containing $\mathrm{K}_{3}$ EDTA, and plasma was prepared by centrifugation within $20 \mathrm{~min}$. Plasma samples were stored at $-20^{\circ} \mathrm{C}$ until analyzed for concentrations of glucose (glucose kit number 315; Sigma), insulin (insulin kit number TKIN; Diagnostic Products Corp., Los Angeles, CA), NEFA (NEFA-C kit number 994-75409; WAKO, Richmond, VA), BHBA (BHBA kit number 310-A; Sigma), PUN (kit number 640; Sigma), and $\alpha$-amino N (AMN). Plasma AMN concentrations were determined as based on the assay of Palmer and Peters (1969): $200 \mu \mathrm{l}$ of sample was filtered through a 3000 molecular weight filter (Microcon YM-3 tube, Millipore, Bedford, MA) for $60 \mathrm{~min}$ at $14,000 \times \mathrm{g}$. To $10 \mu \mathrm{l}$ of supernatant, $80 \mu \mathrm{l}$ of $0.1 \%$ Brij 35 (30\%, wt/vol, polyoxyethylene 23 lauryl ether; catalog number 430AG-6; Sigma) in $0.15 \mathrm{M} \mathrm{NaCl}$, $60 \mu \mathrm{l}$ of $0.05 M$ borate buffer containing $0.1 \%$ Brij 35 (pH 
9.2), and $30 \mu \mathrm{l}$ of $0.1 \% 2,4,6$-trinitrobenzene sulfonate (catalog number P 2297; Sigma) were added. The mixture was stored for $15 \mathrm{~min}$ at room temperature, and then $60 \mu \mathrm{l}$ of $1 \mathrm{M} \mathrm{HCl}$ was added. Absorbance was measured at $340 \mathrm{~nm}$ at room temperature. Aprotinin (Boehringer-Mannheim, Indianapolis, IN) was added at $500 \mathrm{KIU}$ to $1 \mathrm{ml}$ of plasma to be analyzed for glucagon, and samples were stored in glass tubes at $-20^{\circ} \mathrm{C}$. Contrary to the manufacturer's instructions and in contrast to the effects of $\mathrm{Na}_{3}$-EDTA as anticoagulant, $\mathrm{K}_{3}$ EDTA interfered with the analysis of glucagon samples (glucagon kit number KGND1; Diagnostic Products Corp., Los Angeles, CA) and, therefore, data for concentrations of plasma glucagon cannot be reported.

Feed intake and milk. Postpartal feed intake was measured twice daily until d 43. Body weight was measured at $d-4,3,8,11,15,22,28,36$, and 43 postpartum. Cows were milked at 0630 and $1830 \mathrm{~h}$, and milk production was recorded for each milking until d 43 postpartum. Representative samples of the two milkings at $d$ 3,8 (before first injection), 11, 15, 22 (before last injection), 25, 28, 36, and 43 postpartum were analyzed separately for protein, fat, lactose, and urea $\mathrm{N}$ by mid-infrared spectrophotometry (Milk-O-Scan 203, Foss Food Technology, Eden Prairie, MN).

\section{Statistical Analysis}

Data were analyzed as a repeated measures study by using the mixed models procedures of SAS Version 8.2 (2001). The dependent variable was the change of the response variable from the concentration at $\mathrm{d} 8$ postpartum (the last time point before glucagon injections started) to the concentrations at $d 1$ (only for plasma samples), 3, 7, and 14 of injection. For plasma insulin and NEFA responses, the changes were calculated from log-transformed concentrations because the nontransformed values were not normally distributed as required for a valid analysis of variance (Snedecor and Cochran, 1989). The nontransformed values, however, as individual values and as averages were within the ranges normally reported for cows in the postpartal period (Veenhuizen et al., 1991; Hippen et al., 1999; She et al., 1999). The $P$-values of plasma insulin and NEFA reported in the Results and Discussion sections and in the figures are the probabilities of the log-transformed data.

The fixed effects were concentration of the response variable at $d 8$ postpartum (as a linear covariate), treatment (saline normal, saline susceptible, $7.5 \mathrm{mg} / \mathrm{d}$, or 15 $\mathrm{mg} / \mathrm{d}$ ), day of injection ( 1 only for plasma samples, 3 , 7 , or 14), ambient temperature (normal or $>35^{\circ} \mathrm{C}$ ), age of cow ( $<3.5 \mathrm{yr}$ or $>3.5 \mathrm{yr})$, treatment $\times$ day of injection interaction, treatment $\times$ ambient temperature interac- tion, and treatment $\times$ age of cow interaction. A completely unrestricted variance-covariance matrix (for day of injection) was used to account for repeated measures taken on individual cows across time. The response variable at $d 8$ postpartum was included in the model because it had significant effects. For the liver TAG and the plasma insulin and NEFA response, the linear covariate was their respective log-transformed concentration at $\mathrm{d} 8$ postpartum because the residuals for the statistical model containing the log-transformed concentrations but not the model containing the nontransformed concentrations as covariates were randomly distributed.

Ambient temperature was included in the model because hot ambient temperature decreased feed intake and caused metabolic changes similar to a feed restriction protocol (Veenhuizen et al., 1991). Age of cow was included in the model because age of cow significantly affected the response of blood and liver parameters to injections of glucagon. We chose age of cow instead of parity to have four cows in each treatment by age of cow group for the saline susceptible and $15 \mathrm{mg} / \mathrm{d}$ group. Furthermore, in contrast to cows $>3.5 \mathrm{yr}$, the younger cows were still growing. Otherwise, age of cow could have been substituted for parity of cow without affecting the results.

The effects of 7.5 or $15 \mathrm{mg} / \mathrm{d}$ of glucagon were evaluated by comparing their estimated changes from concentrations at $\mathrm{d} 8$ postpartum averaged across day of injection (1 only for plasma variables, 3, 7, and 14) with the corresponding estimated change of the saline susceptible group using a $t$-test in the ESTIMATE statement. The effects of $15 \mathrm{mg} / \mathrm{d}$ of glucagon in cows $<3.5 \mathrm{yr}$ or $>3.5 \mathrm{yr}$ were evaluated by comparing their estimated changes from concentrations at d 8 postpartum averaged across day of injection ( 1 only for plasma variables, 3, 7, and 14) with the corresponding estimated change of the corresponding saline susceptible by age of cow group using a $t$-test in the ESTIMATE statement. The effects of elevated concentrations of liver TAG (susceptible) were evaluated by comparing the estimated concentration at $\mathrm{d} 8$ postpartum of the saline susceptible, 7.5 and $15 \mathrm{mg} / \mathrm{d}$ groups combined with the corresponding estimated concentration of the saline normal group using a $t$-test in the ESTIMATE statement.

To obtain the correct degrees of freedom, the KENWARDROGER option was invoked. The KENWARDROGER option consists of the Satterthwaite adjustment for degrees of freedom with a Kenward-Roger adjustment on standard errors, which can be used for repeated measures studies (Douglass, 2002; Tempelman, 2002). Means and SEM presented in figures are raw means and SEM. Significance was declared at $P \leq$ 
0.05 , and tendency of significance was declared at $P$ $\leq 0.10$.

\section{RESULTS}

Liver. Susceptible cows had higher concentrations of TAG at $\mathrm{d} 8$ postpartum than did normal cows $(P \leq 0.01$; Figure 1A). Injections of $15 \mathrm{mg} / \mathrm{d}$ of glucagon decreased concentrations of TAG immediately in cows older than $3.5 \mathrm{yr}(P \leq 0.02 ; \mathrm{n}=4)$, whereas concentrations of TAG increased initially before they decreased in cows younger than $3.5 \mathrm{yr}(P \leq 0.007 ; \mathrm{n}=4$; Figure 1B). Susceptible cows had lower concentrations of glycogen at d 8 postpartum than did normal cows $(P \leq 0.04$; Figure $1 C)$. The glycogen response to glucagon injections was not significant $(P \leq 0.70$; Figure $1 C)$. Numerically, however, glucagon injections decreased concentrations of glycogen $0.26 \%$ (SEM $=0.29) 3 \mathrm{~d}$ after the first injection and increased concentrations of glycogen $0.35 \%$ (SEM $=1.65$ ) until the end of the $14 \mathrm{~d}$ injection period, with both effects numerically slightly stronger at the $15 \mathrm{mg} /$ $\mathrm{d}$ dosage (Figure 1C). The increase in hepatic glycogen in response to injections of $15 \mathrm{mg} / \mathrm{d}$ of glucagon was earlier in older cows than in younger cows (Figure 1D).

Plasma. Injections of 7.5 and $15 \mathrm{mg} / \mathrm{d}$ of glucagon increased overall concentrations of glucose 17 and 22 $\mathrm{mg} / \mathrm{dl} 1 \mathrm{~h}$ after injection, respectively (both $P \leq 0.0001$; Figure 2A). The increased concentrations of glucose were not only sustained over the entire period of glucagon injection $(P \leq 0.004)$ but even increased an additional $6.7(P \leq 0.007)$ and $4.2 \mathrm{mg} / \mathrm{dl}(P \leq 0.08)$ during the injection period for injections of 7.5 and $15 \mathrm{mg} / \mathrm{d}$ of glucagon, respectively (Figure 2A). The increase in concentrations of glucose was greater in the younger cows (Figure 2B). The glucose response increased in a dose-dependent manner in older cows $(P \leq 0.04$; data not shown). Injections of $7.5(P \leq 0.002)$ and $15 \mathrm{mg} / \mathrm{d}$ of glucagon $(P \leq 0.0001)$ increased concentrations of insulin (Figure 2C). The insulin response increased in a dose-dependent manner in older cows $(P \leq 0.02)$. The insulin response as well as the liver glycogen response to $15 \mathrm{mg} / \mathrm{d}$ of glucagon injections were earlier in older cows than in younger cows (Figures 1D and 2D).

Glucagon injections decreased concentrations of NEFA ( $P \leq 0.008$; Figure 3A). Glucagon injections did not significantly affect concentrations of BHBA $(P \leq$ 0.94; Figure 3B). Overall, glucagon injections tended to decrease AMN concentrations $(P \leq 0.09$; Figure $3 \mathrm{C})$. Glucagon injections decreased AMN concentrations in older cows $(P \leq 0.02)$ but not significantly in younger cows $(P \leq 0.64$; data not shown). Overall, glucagon injections did not affect concentrations of PUN $(P \leq 0.97$; Figure 3D). There was a glucagon $\times$ age interaction $(P$ $\leq 0.05$ ) with increased concentrations of PUN in older
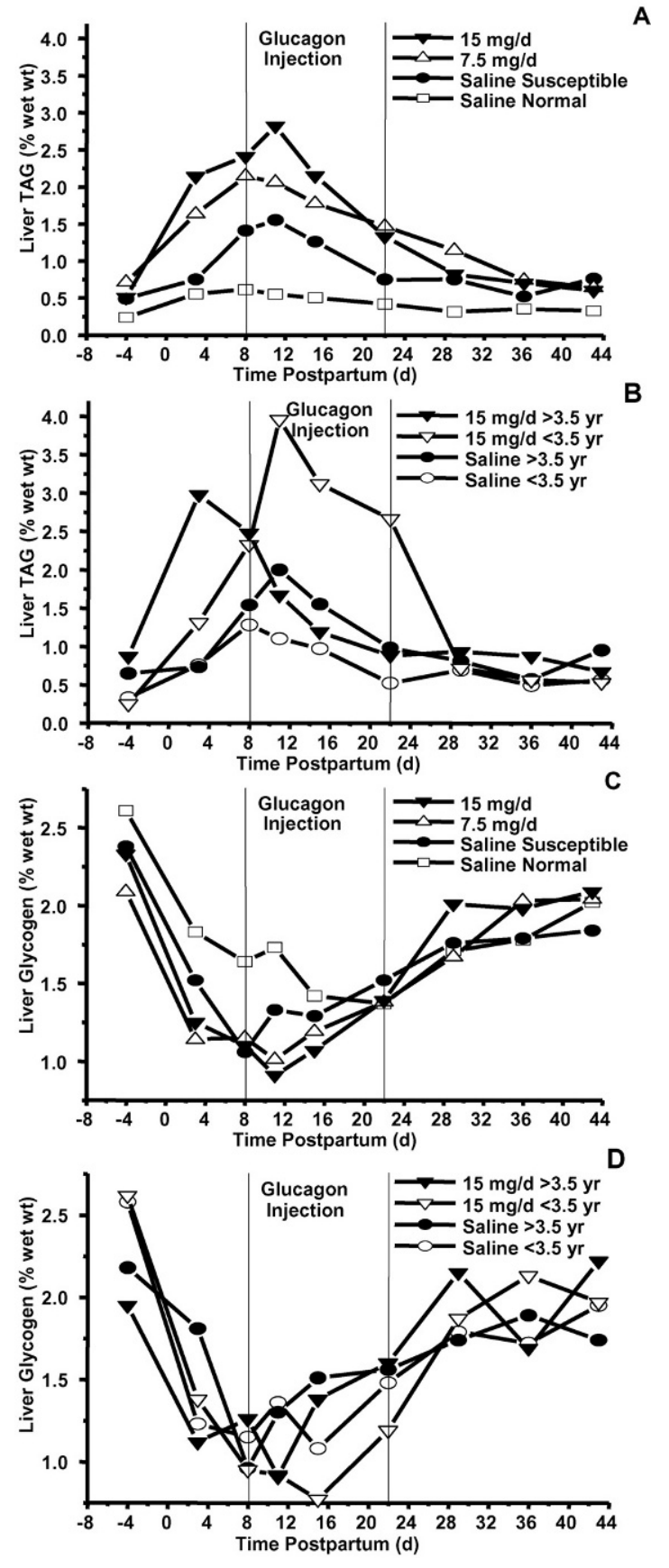

Figure 1. Effect of 7.5 and $15 \mathrm{mg} / \mathrm{d}$ of glucagon and elevated liver triacylglycerol (TAG) concentrations (Susceptible) on concentrations of liver TAG (A and B) and glycogen (C and D) overall (A and C; $n$ $=8$ in each treatment group) and as affected by age of cows (B and $\mathrm{D} ;<3.5 \mathrm{yr}$ or $>3.5 \mathrm{yr} ; \mathrm{n}=4$ in each treatment by age interaction group). A. Effect of Susceptible $(P \leq 0.01), 7.5 \mathrm{mg} / \mathrm{d}(P \leq 0.38)$, and $15 \mathrm{mg} / \mathrm{d}$ of glucagon $(P \leq 0.56)$ on liver TAG $(\mathrm{SEM}=0.08$ to 0.79$)$. B. Effect of $15 \mathrm{mg} / \mathrm{d}$ of glucagon by age interaction $(P \leq 0.0001)$, effect of $15 \mathrm{mg} / \mathrm{d}$ in cows $<3.5 \mathrm{yr}(P \leq 0.007)$, and effect of $15 \mathrm{mg} / \mathrm{d}$ in cows $>3.5 \mathrm{yr}(P \leq 0.02)$ on liver TAG (SEM $=0.02$ to 0.96$)$. C. Effect of Susceptible $(P \leq 0.04), 7.5 \mathrm{mg} / \mathrm{d}(P \leq 0.82)$, and $15 \mathrm{mg} / \mathrm{d}$ of glucagon $(P \leq 0.34)$ on liver glycogen (SEM $=0.07$ to 0.47$)$. D. Effect of $15 \mathrm{mg} /$ d of glucagon $\times$ age interaction $(P \leq 0.92)$, effect of $15 \mathrm{mg} / \mathrm{d}$ in cows $<3.5 \mathrm{yr}(P \leq 0.48)$, and effect of $15 \mathrm{mg} / \mathrm{d}$ in cows $>3.5 \mathrm{yr}(P \leq 0.49)$ on liver glycogen (SEM $=0.06$ to 0.87 ). 

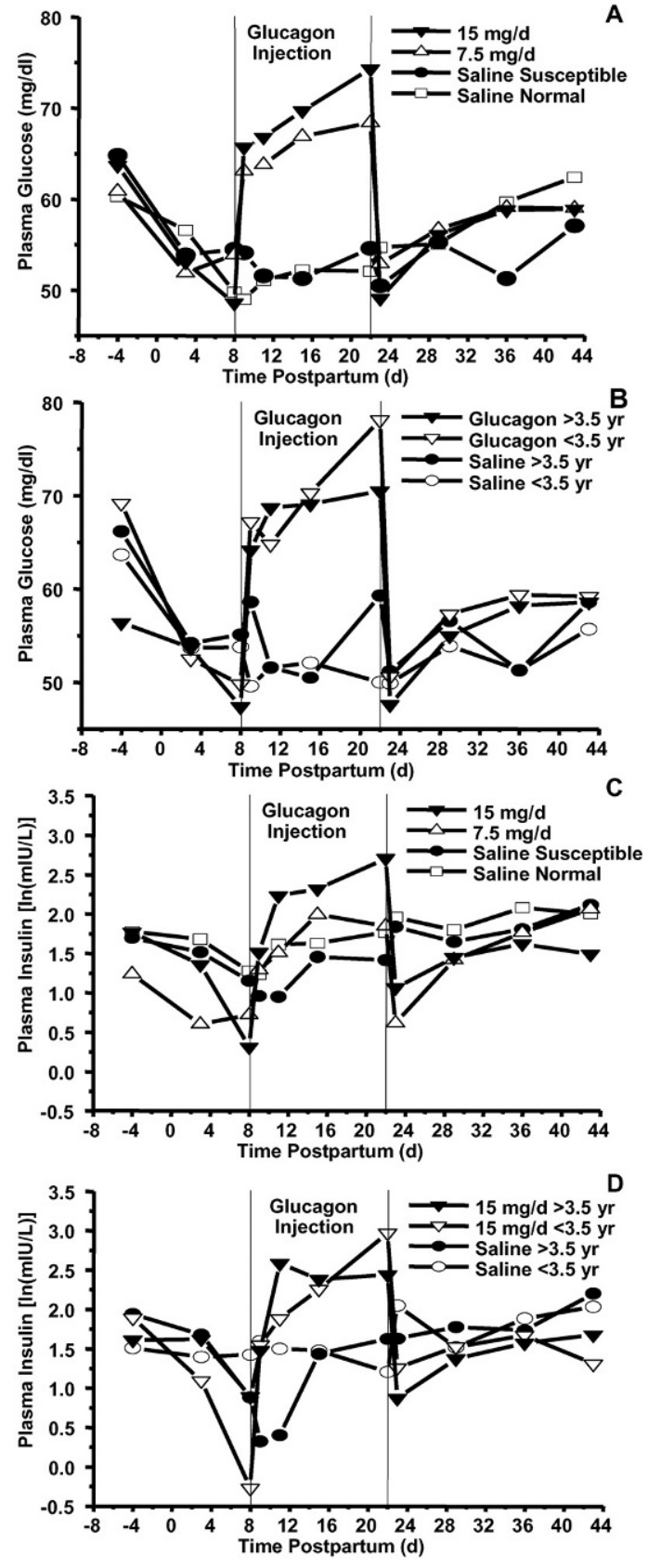

Figure 2. Effect of 7.5 and $15 \mathrm{mg} / \mathrm{d}$ of glucagon and elevated liver triacylglycerol (TAG) concentrations (Susceptible) on concentrations of plasma glucose (A and B) and insulin (C and D) overall (A and C; $\mathrm{n}=8$ in each treatment group) and as affected by age of cow (B and $\mathrm{D} ;<3.5 \mathrm{yr},>3.5 \mathrm{yr} ; \mathrm{n}=4$ in each treatment $\times$ age interaction group). A. Effect of Susceptible $(P \leq 0.33), 7.5 \mathrm{mg} / \mathrm{d}(P \leq 0.0001)$, and $15 \mathrm{mg} /$ $\mathrm{d}$ of glucagon $(P \leq 0.0001)$ on plasma glucose $(\mathrm{SEM}=1.0$ to 4.2$)$. $\mathrm{B}$. Effect of $15 \mathrm{mg} / \mathrm{d}$ of glucagon by age interaction $(P \leq 0.16)$, effect of $15 \mathrm{mg} / \mathrm{d}$ in cows $<3.5 \mathrm{yr}(P \leq 0.0001)$, and effect of $15 \mathrm{mg} / \mathrm{d}$ in cows $>3.5 \mathrm{yr}(P \leq 0.0003)$ on plasma glucose $(\mathrm{SEM}=0.6$ to 7.7$)$. C. Effect of Susceptible $(P \leq 0.17), 7.5 \mathrm{mg} / \mathrm{d}(P \leq 0.002)$, and $15 \mathrm{mg} / \mathrm{d}$ of glucagon $(P \leq 0.0001)$ on log-transformed values of plasma insulin $(\mathrm{SEM}=0.07$ to 0.49$)$. D. Effect of $15 \mathrm{mg} / \mathrm{d}$ of glucagon by age interaction $(P \leq 0.97)$ effect of $15 \mathrm{mg} / \mathrm{d}$ in cows $<3.5 \mathrm{yr}(P \leq 0.006)$, and effect of $15 \mathrm{mg} / \mathrm{d}$ in cows $>3.5 \mathrm{yr}(P \leq 0.0002)$ on log-transformed values of plasma insulin (SEM $=0.06$ to 0.95 ).
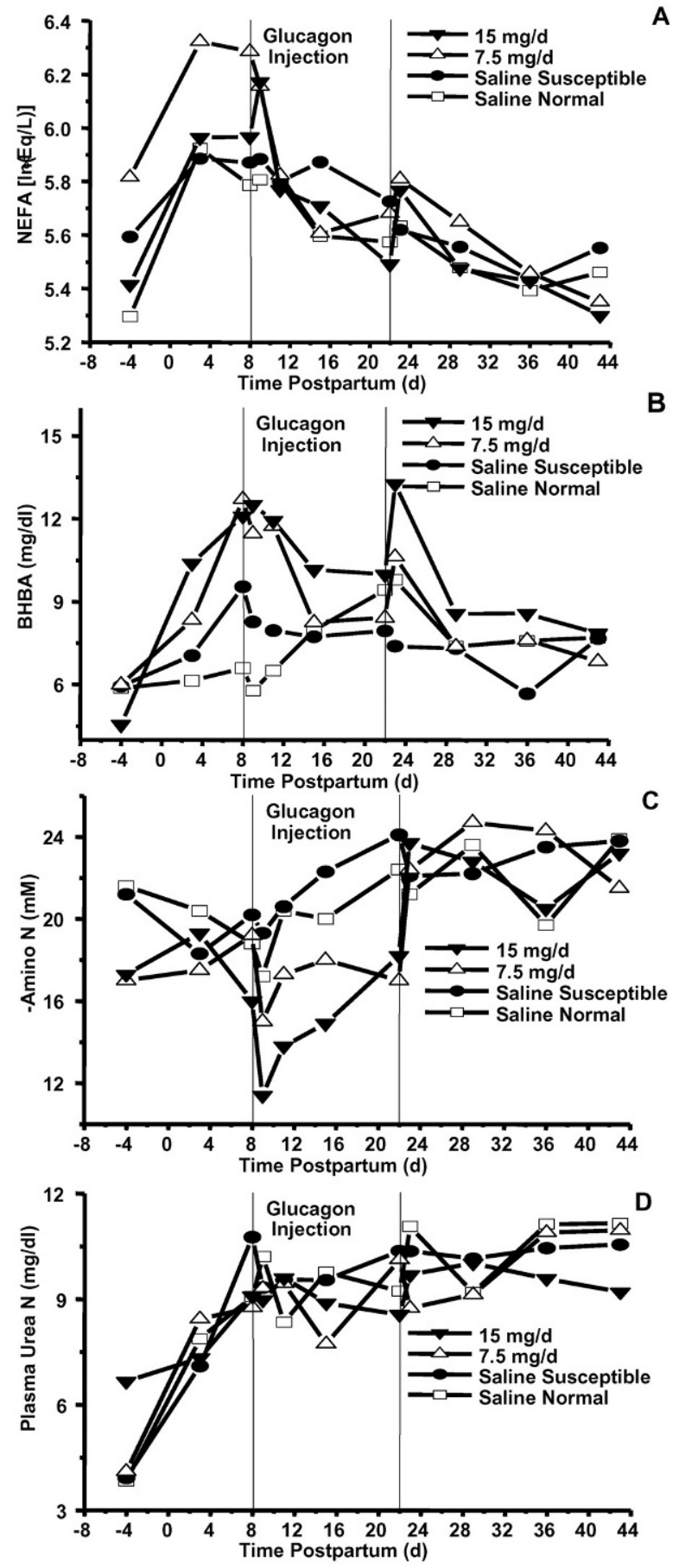

Figure 3. Effect of 7.5 and $15 \mathrm{mg} / \mathrm{d}$ of glucagon and elevated liver triacylglycerol (TAG) concentrations (Susceptible) on concentrations of plasma NEFA, BHBA, $\alpha$-amino N (AMN), and urea N (PUN; $\mathrm{n}=$ 8 in each treatment group). A. Effect of Susceptible $(P \leq 0.37), 7.5$ $\mathrm{mg} / \mathrm{d}(P \leq 0.004)$, and $15 \mathrm{mg} / \mathrm{d}$ of glucagon $(P \leq 0.08)$ on log-transformed values of plasma NEFA (SEM $=0.06$ to 0.21 ). B. Effect of Susceptible $(P \leq 0.17), 7.5 \mathrm{mg} / \mathrm{d}(P \leq 0.81)$, and $15 \mathrm{mg} / \mathrm{d}$ of glucagon $(P \leq 0.69)$ on plasma BHBA (SEM $=0.8$ to 3.3). C. Effect of Susceptible $(P \leq$ $0.66), 7.5 \mathrm{mg} / \mathrm{d}(P \leq 0.21)$, and $15 \mathrm{mg} / \mathrm{d}$ of glucagon $(P \leq 0.09)$ on plasma AMN (SEM $=1.1$ to 3.3). D. Effect of Susceptible $(P \leq 0.63)$, $7.5 \mathrm{mg} / \mathrm{d}(P \leq 0.78)$, and $15 \mathrm{mg} / \mathrm{d}$ of glucagon $(P \leq 0.70)$ on plasma PUN (SEM $=0.6$ to 2.2 ). 
cows $(P \leq 0.07)$ and decreased concentrations of PUN in younger cows ( $P \leq 0.21$; data not shown).

Body weight, DMI, milk production, and composition. Body weight and DMI were not affected by glucagon injections $(P \leq 0.26$ and $P \leq 0.41$; Figure $4 \mathrm{~A})$ irrespective of cow age or ambient temperature. Milk production $(P \leq 0.52$; Figure $4 \mathrm{~B})$ and concentrations and production of milk fat $(P \leq 0.94$ and $P \leq 0.49$; data not shown) and lactose $(P \leq 0.55$ and $P \leq 0.85$; data not shown) were not significantly affected by glucagon injection. Overall, glucagon injections decreased concentrations and production of milk protein $(P \leq 0.03$ and $P \leq 0.05$; Figure $4 \mathrm{C}$ ) and tended to decrease concentrations of milk urea $\mathrm{N}(P \leq 0.10$; Figure $4 \mathrm{D})$. The effects were numerically stronger at the $15-\mathrm{mg} / \mathrm{d}$ dosage. Injections of 7.5 and $15 \mathrm{mg} / \mathrm{d}$ of glucagon decreased concentrations of protein $0.15 \%$ (SEM $=0.11 ; P \leq 0.18)$ and $0.28 \%(\mathrm{SEM}=0.10 ; P \leq 0.01)$, respectively (Figure $4 \mathrm{C})$.

\section{DISCUSSION}

The objective of the current study was to determine whether subcutaneous injections of 7.5 and $15 \mathrm{mg} / \mathrm{d}$ of glucagon for $14 \mathrm{~d}$ starting at $\mathrm{d} 8$ postpartum can be used to treat fatty liver similarly to continuous, intravenous infusions of $10 \mathrm{mg} / \mathrm{d}$ of glucagon (Hippen et al., 1999). The results demonstrate that subcutaneous injections of $15 \mathrm{mg} / \mathrm{d}$ of glucagon decrease concentrations of liver TAG in cows older than $3.5 \mathrm{yr}$ (Figures $1 \mathrm{~A}$ and B) and, therefore, have the potential to treat fatty liver. These results are similar to the effect of continuous, intravenous infusions of $10 \mathrm{mg} / \mathrm{d}$ of glucagon in cows that were subjected to a fatty liver induction protocol, because 9 of the 10 cows treated with glucagon in that study were over 3.5 yr old (Hippen et al., 1999). Neither metabolic problems post calving nor BCS can explain the different responses to glucagon between age groups because both variables were similar in both age groups (Table 2). It cannot be excluded that differences in prepartum DMI could partly explain the different responses to glucagon because individual prepartal DMI was not completely controlled. Differences in prepartal DMI between age of cow-groups within treatment, however, are unlikely because there were no significant differences in changes of BCS during the last month before parturition (Table 2 ). We can, therefore, only speculate why the younger cows did not respond to injections of glucagon similar to the older cows, because the metabolic response of the younger cows to injections of glucagon differed among the younger cows. A heterogeneous response to injections of glucagon among cows with clinical fatty liver has been observed previously by Steen et al. (1997) and can be explained partly by the heterogeneous etiologies that cause fatty liver (Herdt, 1988; Holtenius and Hol-
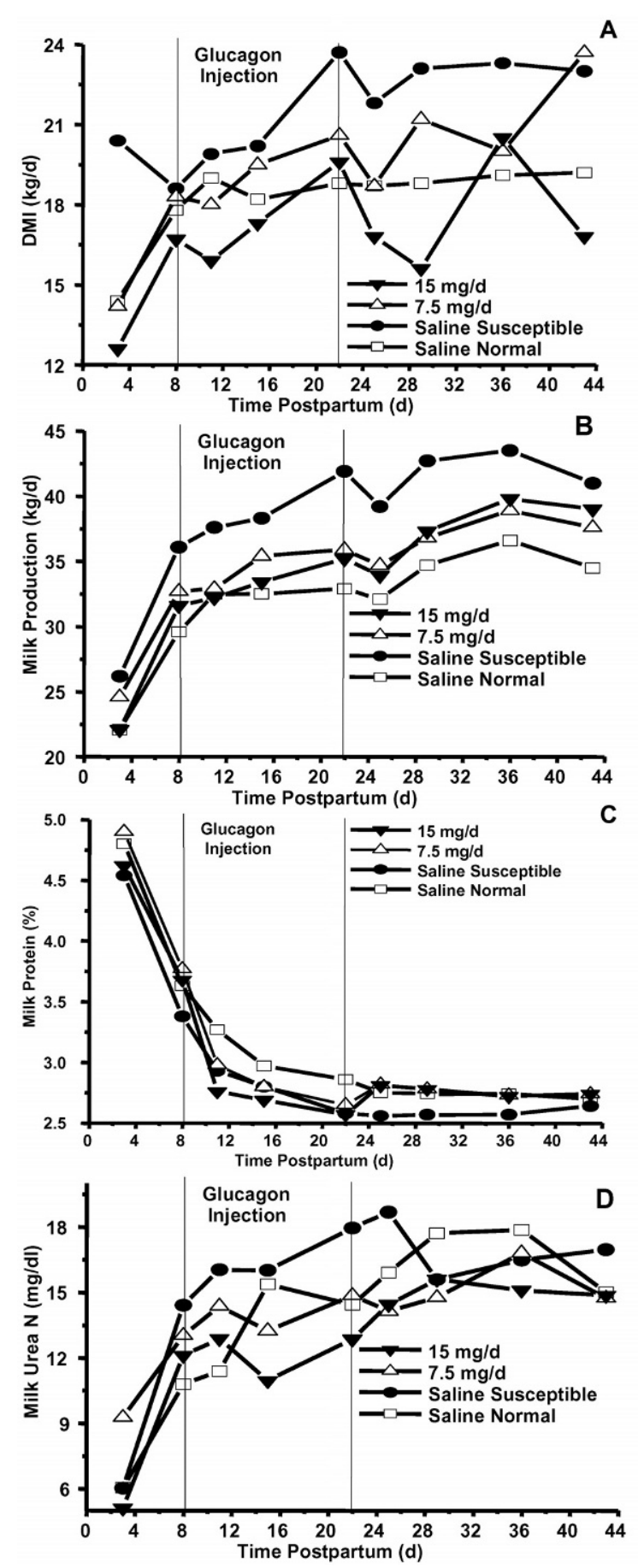

Figure 4. Effect of 7.5 and $15 \mathrm{mg} / \mathrm{d}$ of glucagon and elevated liver triacylglycerol (TAG) concentrations (Susceptible) on DMI, milk production, and concentrations of milk protein and urea $\mathrm{N}(\mathrm{n}=8$ in each treatment group). A. Effect of Susceptible $(P \leq 0.84), 7.5 \mathrm{mg} / \mathrm{d}$ $(P \leq 0.69)$, and $15 \mathrm{mg} / \mathrm{d}$ of glucagon $(P \leq 0.28)$ on DMI (SEM $=0.8$ to 3.0). B. Effect of Susceptible $(P \leq 0.48), 7.5 \mathrm{mg} / \mathrm{d}(P \leq 0.48)$, and 15 $\mathrm{mg} / \mathrm{d}$ of glucagon $(P \leq 0.69)$ on milk production $(\mathrm{SEM}=1.6$ to 4.7$)$. C. Effect of Susceptible $(P \leq 0.75), 7.5 \mathrm{mg} / \mathrm{d}(P \leq 0.18)$, and $15 \mathrm{mg} / \mathrm{d}$ of glucagon $(P \leq 0.01)$ on milk protein concentrations $(\mathrm{SEM}=0.04$ to 0.64$)$. D. Effect of Susceptible $(P \leq 0.20), 7.5 \mathrm{mg} / \mathrm{d}(P \leq 0.20)$, and $15 \mathrm{mg} / \mathrm{d}$ of glucagon $(P \leq 0.09)$ on milk urea $\mathrm{N}$ concentrations (SEM $=0.7$ to 2.3 ). 
tenius, 1996). Younger cows partition fewer gluconeogenic precursors for gluconeogenesis because they are still growing; however, the plasma glucose response to glucagon injections was greater in younger cows than it was in older cows (Figure 2B). Another possible explanation is that younger cows might have a different glucagon response than do older cows (Teillet et al., 2002), which could explain why plasma insulin and liver TAG and glycogen responses to glucagon injections started a few days later in younger cows than in older cows (Figures 1C, 1D, and 2D).

Any ineffectiveness of injections of glucagon in younger cows is not a major problem, because fatty liver is a far greater problem in older cows than in younger cows (Reid 1980) and might be partly alleviated by dietary supplementation of gluconeogenic precursors. Further, increased daily dosages of glucagon could improve the beneficial responses in cows of all ages. In comparison to continuous, intravenous infusions of 10 mg/d of glucagon (Hippen et al., 1999; She et al., 1999), the metabolic responses to subcutaneous injections of 7.5 and $15 \mathrm{mg} / \mathrm{d}$ of glucagon (Figures 1 to 4) were smaller, because the glucagon transfer rate into plasma was smaller for single subcutaneous injections of 2.5 and $5 \mathrm{mg}$ of glucagon than for continuous, intravenous infusions of $10 \mathrm{mg} / \mathrm{d}$ of glucagon (Bobe et al., 2003; Hippen et al., 1999; She et al., 1999).

Glucagon injections decreased concentrations of plasma NEFA (Figure 3A). The response to glucagon injections was stronger in cows with higher preinjection NEFA concentrations (Bobe et al., 2003), which could explain the greater effect of the lower glucagon dosage because those cows had higher preinjection NEFA concentrations (Figure 3A). The higher incidence of elevated concentrations of plasma NEFA at d 8 postpartum with the lower glucagon dosage was not associated with differences in BCS or health status (Table 2). A possible explanation is that glucagon injections decrease lipolysis to baseline values for each particular stage of lactation, and, therefore, no NEFA response to glucagon can be detected at lower preinjection NEFA concentrations. The lower concentrations of BHBA in the current study (Figure 3B), in comparison to those of Hippen et al. (1999), also could explain why we did not detect significant BHBA responses to glucagon injection as in another study from our group (Bobe et al., 2003). Another reason for the greater effect of the lower glucagon dosage could be that the higher glucagon dosage increases lipolysis in the absence of an insulin response to glucagon injection, which could explain the numerically increased concentrations of plasma BHBA and NEFA at the beginning of the injection period. De Boer et al. (1986) demonstrated similar responses in ketotic and early-lactation cows after glucagon injec- tions. Glucagon is known to increase lipolysis and ketogenesis (Brockman et al., 1976; Zupke et al., 1998), but its effect is negated by increased insulin concentrations (Brockman et al., 1976).

Subcutaneous injections of glucagon did not decrease DMI or milk production (Figures $4 \mathrm{~A}$ and $\mathrm{B}$ ) as did continuous infusions of glucagon in a previous study (Hippen et al., 1999; She et al., 1999). Therefore, subcutaneous injections of glucagon seem to be a more realistic choice for treatment of fatty liver than do intravenous infusions. The lack of effect could be related to the smaller metabolic responses to subcutaneous injections of 7.5 and $15 \mathrm{mg} / \mathrm{d}$ of glucagon (Figures 1 to 4 ) in comparison to continuous, intravenous infusions of $10 \mathrm{mg} / \mathrm{d}$ of glucagon (Hippen et al., 1999; She et al., 1999). Another reason could be the mode of administration (multiple injections vs. continuous infusions), which allows the glucagon and insulin concentrations to regain physiological concentrations between injections (Geary, 1996; Bobe et al., 2003). Similar to our results, Trevisi et al. (1997a,b) detected decreased milk production only in cows receiving continuous infusions of glucagon but not in cows receiving injections. The only potential disadvantage of subcutaneous injections is that concentrations of milk protein are decreased during the glucagon injection period (Figure 4C; Trevisi et al., 1997b). This effect could be related to glucagon causing increased hepatic amino acid uptake and thereby decreasing amino acid availability of tissues without glucagon receptors (Flakoll et al., 1994; Dunphy et al., 1998). That hypothesis is supported by the results in the current study (Figures 3C and 4C). Concentrations of milk protein were not different between saline- and glucagontreated cows (Figure 4C), and decreased concentrations of milk proteins might be alleviated by supplementation of gluconeogenic precursors in the diet during glucagon injection periods (Gill et al., 1985).

\section{CONCLUSIONS}

The current study demonstrates that subcutaneous injections of $15 \mathrm{mg} / \mathrm{d}$ of glucagon for $14 \mathrm{~d}$ beginning at d 8 postpartum decreases liver TAG concentrations in cows older than $3.5 \mathrm{yr}$; therefore, glucagon has the potential to treat fatty liver, a major metabolic disorder in early lactation dairy cows. In comparison to continuous, intravenous infusion, which is the other known treatment for fatty liver, multiple subcutaneous injections have fewer negative side effects (decreases in milk production and DMI) and are much more practical for onfarm use.

\section{ACKNOWLEDGMENTS}

The authors thank Swiss Valley Farms (Davenport, IA) for analysis of milk samples and Eli Lilly (Indianap- 
olis, IN) for donation of glucagon. The research was partly supported by grant number 99-35005-8576 from the US Department of Agriculture and was part of regional research project NC-185. Appreciation is extended to the management of the Iowa State University Dairy Teaching Herd for provision of cows, to K. J. Koehler for assistance in statistical analyses, and to Y. Lu, R. A. Nafikov, R. Sonon, and many undergraduate and veterinary medical students for assistance in collecting and analyzing liver and blood samples.

\section{REFERENCES}

Bobe, G., R. N. Sonon, B. N. Ametaj, J. W. Young, and D. C. Beitz. 2003. Metabolic responses of lactating dairy cows to single and multiple injections of glucagon. J. Dairy Sci. 86:2072-2081.

Brockman, R., E. N. Bergman, P. K. Joo, and J. G. Manns. 1975. Effects of glucagon and insulin on net hepatic metabolism of glucose precursors in sheep. Am. J. Physiol. 229:1344-1350.

De Boer, G., A. Trenkle, and J. W. Young. 1986. Secretion and clearance rates of glucagon in dairy cows. J. Dairy Sci. 69:721-733.

Donkin, S. S., and L. E. Armentano. 1995. Insulin and glucagon regulation of gluconeogenesis in preruminating and ruminating bovine. J. Anim. Sci. 73:546-551.

Douglass, L. W. 2002. Analysis of correlated measures: Temporally related observations, repeated measures analysis. Pages 10-15 in NCR-170 FASS Mixed Model Workshop. 2002 ADSA-ASASCSAS Natl. Mtg., Quebec City, QC, Canada.

Dunphy, J. L., R. G. Taylor, and P. J. Fuller. 1998. Tissue distribution of rat glucagon receptor and GLP-1 receptor gene expression. Mol. Cell. Endocrinol. 1998:179-186.

Edmonson, A. J., I. J. Lean, L. D. Weaver, T. Farver, and G. Webster. 1989. A body condition scoring chart for Holstein dairy cows. J. Dairy Sci. 72:68-78.

Flakoll, P. J., M. J. Borel, L. S. Wentzel, P. E. Williams, D. B. Lacy, and N. N. Abumrad. 1994. The role of glucagon in the control of protein and amino acid metabolism in vivo. Metabolism 43:1509-1516.

Geary, N. 1996. Glucagon and the control of appetite. Pages 223238 in Glucagon III. Handbook of Experimental Pharmacology. P. J. Lefêbvre, ed. Springer-Verlag, Berlin, Germany.

Gill, W., G. E. Mitchell, Jr., J. A. Boling, R. E. Tucker, G. T. Schelling, and R. M. DeGregorio. 1985. Glucagon influence on gluconeogenesis and oxidation of propionic acid and threonine by perfused ovine liver. J. Dairy Sci. 68:2886-2894.

Hippen, A. R., P. She, J. W. Young, D. C. Beitz, G. L. Lindberg, L. F. Richardson, and R. W. Tucker. 1999. Alleviation of fatty liver in dairy cows with 14-day intravenous infusions of glucagon. J. Dairy Sci. 82:1139-1152.

Holtenius, P., and K. Holtenius. 1996. New aspects of ketone bodies in energy metabolism of dairy cows: a review. J. Vet Med. Ser. A $43: 579-587$.

Herdt, T. H. 1988. Fatty liver in dairy cows. Vet. Clin. North Am. Food Anim. Pract. 4:269-287.

Jorritsma, R., H. Jorritsma, Y. H. Schukken, P. C. Bartlett, T. Wensing, and G. H. Wentink. 2001. Prevalence and indicators of post partum fatty infiltration of the liver in nine commercial dairy herds in The Netherlands. Livest. Prod. Sci. 68:53-60.

Littledike, E. T., J. W. Young, and D. C. Beitz. 1981. Common metabolic diseases of cattle: Ketosis, milk fever, grass tetany, and downer cow complex. J. Dairy Sci. 64: 1465-1482.

Murondoti, A., M. T. Tivapasi, M. J. H. Geelen, T. Wensing, and A. C. Beynen. 2002. The effect of postpartum rumen undegradable protein supplementation on hepatic gluconeogenic enzyme activities in dairy cows with fatty liver. Int. J. Vitm. Nutr. Res. 72:336-340.

Nafikov, R. A., B. N. Ametaj, G. Bobe, J. W. Young, and D. C. Beitz. 2002. Prevention of fatty liver in transition dairy cows by glucagon. J. Dairy Sci. 85(Suppl. 1):21. (Abstr.)

National Research Council. 2001. Nutrient Requirements of Dairy Cattle. 7th rev. ed. Natl. Acad. Sci., Washington, DC.

Rehage, J., M. Mertens, N. Stockhofe-Zurwieden, M. Kaske, and H. Scholz. 1996. Post surgical convalescence of dairy cows with left abomasal displacement in relation to fatty liver. Schweiz. Arch. Tierheilkd. 138:361-368.

Reid, I. M. 1980. Incidence and severity of fatty liver in dairy cows. Vet. Rec. 107:281-284.

Sakai, T., T. Hayakawa, M. Hamakawa, K. Ogura, and S. Kubo. 1993. Therapeutic effects of simultaneous use of glucose and insulin in ketotic dairy cows. J. Dairy Sci. 76:109-114.

Snedecor, G. W., and W. G. Cochran. 1989. Pages 290-296 in Statistical Methods. 8th ed. Iowa State University Press, Ames, IA.

SAS User's Guide: Statistics, Version 8.2. 2001. SAS Inst., Inc., Cary, NC.

She, P., A. R. Hippen, J. W. Young, G. L. Lindberg, D. C. Beitz, L. F. Richardson, and R. W. Tucker. 1999. Metabolic responses of lactating dairy cows to 14-day intravenous infusions of glucagon. J. Dairy Sci. 82:1118-1127.

Shpigel, N. Y., R. Chen, Y. Avidar, and E. Bogin. 1996. Use of corticosteroids alone or combined with glucose to treat ketosis in dairy cows. JAVMA 208:1702-1704.

Steen, A., H. Gørnstøl, and P. A. Torjesen. 1997. Glucose and insulin responses to glucagon injection in dairy cows with ketosis and fatty liver. J. Vet. Med. Ser. A 44:521-530.

Studer, V. A., R. R. Grummer, S. J. Bertics, and C. K. Reynolds. 1993. Effect of prepartum propylene glycol administration on periparturient fatty liver in dairy cows. J. Dairy Sci. 76:29312939 .

Teillet, L., P. Ribière, S. Gouraud, H. Bakala, and B. Corman. 2002. Cellular signaling, AGE accumulation and gene expression in hepatocytes of lean aging rats fed ad libitum or food-restricted. Mech. Aging Dev. 123:427-439.

Tempelman, R. J. 2002. Mixed models and SAS PROC MIXED: An introduction. Pages 11-16 in NCR-170 FASS Mixed Model Workshop. 2002 ADSA-ASAS-CSAS Natl. Mtg., Quebec City, QC, Canada.

Trevisi, E., G. Folli, and G. Bertoni. 1997a. Effect of long term infusion of insulin and glucagon on milk yield and composition of dairy cows. Page 1-10 in 32nd Int. Symp. Anim. Prod. Milan, Italy.

Trevisi, E., M. Nazifi, M. G. Maianti, and G. Bertoni. 1997b. Effect of short treatments with insulin, glucagon, and TRH on metabolic variations, milk yield and quality in dairy cows. Atti Soc. Ital. Sci. Vet. 21:367-368.

Veenhuizen, J. J., J. K. Drackley, M. J. Richard, T. P. Sanderson, L. D. Miller, and J. W. Young. 1991. Metabolic changes in blood and liver during development and early treatment of experimental fatty liver and ketosis in cows. J. Dairy Sci. 74:4238-4253.

Wensing, T., T. Kruip, M. J. H. Geelen, G. H. Wentink, and A. M. van den Top. 1997. Postpartum fatty liver in high-producing dairy cows in practice and in animal studies. The connection with health, production and reproduction problems. Comp. Haematol. Int. 7:167-171.

Zerbe, H., N. Schneider, W. Leibold, T. Wensing, T. A. M. Kruip, and H. J. Schuberth. 2000. Altered functional and immunophenotypical properties of neutrophilic granulocytes in postpartum cows associated with fatty liver. Theriogenology 54:771-786.

Zupke, C. A., P. Stefanovich, F. Berthiaume, and M. L. Yarmush. 1998. Metabolic effects of stress mediators on cultured hepatocytes. Biotechnol. Bioeng. 58:222-230. 